\title{
Graciela Montes y Ema Wolf, El turno del escriba. México, Alfaguara, 2005.
}

La historia de Marco Polo es fascinante: un hombre que en sus larguísimos viajes por tierras inimaginables conoció al Gran Khan y a conquistadores con ejércitos de miles de disciplinados soldados, y fue testigo tanto de guerras espectaculares como de formas exóticas de vida en pueblos donde convivió por años. Y todo ello, en plena Edad Media.

Ese bagaje de experiencias que Marco Polo descubrió a Occidente, relatándolas en su libro Le divisement du monde (Las maravillas del mundo), detonó el contraste del Mundo Occidental y "ese" mundo extraño de Karakorum (China), que por ende debería de ser "el Oriental" de costumbres extrañas y de grandes descubrimientos, como es la pólvora -un ejemplo típico que revolucionó, por su explosiva fuerza, la dinámica de la guerra en Europa desde el Medievo.

Pero este libro no habla de Marco Polo, por muy raro que parezca. Trata de un prisionero desesperado que estaba en su obscura celda en la cárcel del Palazzo del Mare en Venecia, porque tenía ya catorce años de haber sido privado de su libertad. Todos esos años ese hombre había sido llevado de una prisión a otra, sin que nadie le prestara atención, porque según él no debía de estar preso. Curiosamente, 1e "prestaban" la libertad para dar sus servicios a diferentes oficinas públicas, en donde las autoridades ignorantes y hasta casi analfabetas hacían uso de sus buenos y experimentados conocimientos de escritura, aprovechándose de él para que, sin darle su libertad o defenderlo, escribiera documentos oficiales.

Este escriba se llamaba Rustichello. Originario de Pisa, ya era de edad avanzada. Gozaba de gran prestigio en Venecia porque había sido copista de grandes relatos - recordemos que faltaban como 150 años para que Gutenberg inventara la imprenta-, como el de Tristán de Leonnoys en el Cielo de Cornua1les y las cabalgatas de Lancelote por el Bosque de Borceliande. Sin embargo, fue capturado por los venecianos en una batalla y fue mandado a prisión.

Eran en vano las peticiones para ser liberado que casi a diario hacía Rustichello a los encargados de la aduana, que le pedían escribiera los inventarios de la carga de los barcos que transportaban invaluables riquezas a ese importantísimo puerto, o a los jueces, que le pedían que tomara nota para las actas de los juicios importantes, que con seguridad iban a ver los superiores, y sólo alguien como él podría redactar con claridad y hasta bella caligrafía.

Pero, tampoco trata este libro de Rustichello, ese magnífico escriba, incomprendido, que va y viene de la cárcel de Venecia haciendo su oficio de escri- 
tor, y tratando de ganar ciertos privilegios para que su supervivencia no tuviera tanta penuria. No. Más bien, trata de esa fusión pluma-escritor, esa combinación de mente y sentimientos del escriba: del proceso de escribir la obra en la que Marco Polo le relató sus viajes y experiencias. Éste no sólo es el tema central del libro, sino también su valor: la habilidad con la que las autoras argentinas Graciela Montes y Ema Wolf, recrean apasionadamente el proceso de la escritura. Se imaginan cómo Rustichello, hundido en la desesperación de su apestosa celda, gracias a su brillantez de mente, es el único que pudo darse cuenta del valor que tenían los relatos que contaba el tímido viajero con excéntricas ropas: su nuevo compañero de habitación. E1 redactor se imaginó el tremendo impacto que tendría el dar a conocer, por ejemplo, que había una gallina con pelos de gato, y que también ponía huevos comestibles, o acerca de las conversaciones que el Gran Khan y los Polo tuvieron.

Entonces le 1legó el turno al escriba: título de este libro. Rustichello, a pesar de encontrarse en ese ambiente rudo e ignorante de la cárcel, no sólo pensaba que las historias de Marco Polo eran dignas de ser contadas, sino que también reconoció la gran oportunidad que tenía enfrente de poder sorprender al Papa, a algunos nobles y de paso al mundo, con los relatos del veneciano, cuyo impulso podría ser su pasaporte a la libertad.

De ahí en adelante se desenvuelve ante nuestros ojos el difícil pero apasionante proceso de la creación literaria: cómo este escriba de Pisa se las ingenia para reutilizar a escondidas algunos de los pergaminos de la aduana, para escri- bir más tarde los relatos del veneciano. El escriba tiene que enfrentar todo ese tiempo la angustia de pensar que las autoridades podrían cambiar de celda o liberar a Marco Polo, por lo que no podría concluir su majestuosa y liberadora obra.

Rustichello se adaptó al proceso de la escritura cuando pareció descubrir que si no escribía casi inmediatamente 1o que Polo le había contado en la noche, después los detalles se esfumaban, dejando un relato débil y sin importancia. Y resultaba aún más grave que el escritor le pidiera al veneciano que volviera a contar algún pasaje, porque lo podría cambiar mucho, como demostraban los borrones que algunos de estos papiros originales tenían.

Gran dificultad le costaba al escriba recordar los nombres de personajes y lugares tan exóticos que le daba Polo, por lo que tuvo que poner un especial cuidado. Inclusive se sabe que había dibujado Rustichello un mapa de la ruta de la caravana de la familia Polo en un cuarto a donde su carcelero 1o dejaba salir por amistad.

Es conmovedora la manera en que las autoras describen a Rustichello angustiado por conservar y ordenar los papiros de la historia del comerciante; volvía a escribir las partecitas que se le dañaban, que le mordían las ratas o que se borraban porque se le goteaban de agua. Parece ser que encontró un cofre de madera donde los fue acumulando por meses, hasta lograr terminar la obra.

E1 clima les ayudó a ambos para avanzar en el relato debido a que al iniciarse la temporada invernal en Venecia, la actividad del puerto casi se para- 
lizaba, 1o cual se supone le dio más tiempo al escritor de redactar la información que le daba Polo oralmente. Parece ser que cuando la paz del invierno se terminó, y se empezaron a requerir sus servicios de escriba nuevamente, Rustichello decidió terminar la obra. Le dio un final rápido, a pesar de que Polo le insistía en seguir el regreso de su viaje paso a paso.

Rustichello escribió su libro en francés de la corte, provenzal, italiano y latín, con palabras en véneto y en diferentes lenguas que Polo había conocido en sus viajes. Las autoras de este libro, El turno del escriba, redactan la obra en español, y lo salpican de palabras en italiano y latín, para dar la ambientación del lugar y la época. Muchos pasajes en que la narración se detiene, son por descripciones que sirven para demostrar la gran investigación que Montes y Wolf hicieron, durante un tiempo que debe haber sido muy largo, a juzgar por la erudición de los detalles para revivir esa época veneciana.

Las autoras nos introducen en un paisaje costumbrista muy completo, tanto de descripciones físicas de Venecia, como de los personajes y costumbres de la época. Aún así, la mayor motivación para leer este libro es el disfrutar del proceso que Rustichello lleva a cabo para poner por escrito lo que Marco Polo le contaba. Es por ello muy comprensible que este libro haya ganado un premio muy importante este año. 
